\title{
Isotopic evidence for the use of Caucasian antimony in Late Bronze Age glass making
}

\author{
Patrick Degryse ${ }^{a, b, *}$, Andrew J. Shortland ${ }^{c}$, Sarah Dillis ${ }^{a}$, Alicia van Ham-Meert ${ }^{\text {a,d }}$, \\ Frank Vanhaecke ${ }^{\mathrm{e}}$, Peter Leeming ${ }^{\mathrm{f}}$ \\ ${ }^{a}$ Department of Earth and Environmental Sciences, Katholieke Universiteit Leuven, Celestijnenlaan 200 E, 3001, Heverlee, Belgium \\ ${ }^{\mathrm{b}}$ Faculty of Archaeology, Leiden University, Einsteinweg 2, 2333, CC, Leiden, the Netherlands

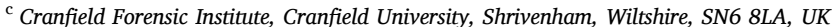 \\ ${ }^{\mathrm{d}}$ Analytical, Environmental and Geo-Chemistry, VUB, Pleinlaan 2, 1050, Brussels, Belgium \\ ${ }^{\mathrm{e}}$ Department of Chemistry, Atomic \& Mass Spectrometry - A\&MS Research Unit, Ghent University, Campus Sterre, Krijgslaan 281 - S12, 9000, Gent, Belgium \\ ${ }^{\mathrm{f}}$ Honorary Research Fellow, University of Exeter, UK
}

\section{A R T I C L E I N F O}

\section{Keywords:}

Antimony

Caucasus

Glass

Isotope ratio

Stibnite

\begin{abstract}
A B S T R A C T
Antimony (Sb) is considered a rare material in the archaeological record, found only in unusual circumstances. Nevertheless, antimony minerals were an important resource for several millennia, used in metallurgy and to opacify or decolour glass and glazes. In this way, Sb spread throughout the known world from the Chalcolithic onward. In glassmaking, stibnite was the only available resource that could provide in any measure the very pure $\mathrm{Sb}$ evident from trace element analyses of the earliest glass. Sb isotopic analysis has allowed Late Bronze Age Egyptian and Mesopotamian glass vessels and Caucasian Sb metallic beads to be compared to the possible ancient ore sources. The only known matches for the isotopic composition of the glass are stibnite ores from the RachaLechkumi district in the Caucasus (present-day Georgia), near the Zopkhito Au-Sb deposits, mined from the 17th century BCE. Conversely, the Sb metal beads represent several isotopic and trace element compositional groups, only one of which matches the Racha-Lechkumi stibnite. Sb extraction for glassmaking was likely unrelated to copper metallurgy, and may have been associated with the mining of precious metals.
\end{abstract}

\section{Introduction}

The vitreous materials industries know a long history of use of antimony (Sb). The widespread adoption of glass as a man-made material started during the 16th century BCE, and factory-based glassmaking has been placed in Mesopotamia and Egypt, with early finds in Syro-Palestine, Mycenae and the Caucasus as well (Shortland, 2012). Sb minerals are a major raw material used as an opacifier, combined with copper $(\mathrm{Cu})$ or cobalt $(\mathrm{Co})$ to make opaque blue glasses, or with calcium ( $\mathrm{Ca}$ ) and lead $(\mathrm{Pb})$ antimonate for the production of opaque white $\left(\mathrm{Ca}_{2} \mathrm{Sb}_{2} \mathrm{O}_{7}\right.$ or $\left.\mathrm{CaSb}_{2} \mathrm{O}_{6}\right)$ and opaque yellow $\left(\mathrm{Pb}_{2} \mathrm{Sb}_{2} \mathrm{O}_{7}\right)$ glass, respectively (Shortland, 2002a). Early glass was an elite material, used as a substitute for semi-precious stone such as lapis and turquoise, whereas the earliest yellow glass may have been equivalent to gold (Au) (Shortland, 2012). Glass technology in Mesopotamia differed subtly from contemporary Egyptian sites, using different ways of opacifying and working glass. At least two, perhaps three, Near Eastern production sites may have existed in addition to the Egyptian sites (Shortland et al., 2018). These glass manufacturing areas are chemically and isotopically distinct (Shortland et al., 2007; Degryse et al., 2010), and raw glass was exchanged very early on, as can be seen from the discovery of 16th-15th century BCE Mesopotamian glass in Egyptian tombs (Kemp et al., 2020), or from the late 14th century BCE Uluburun shipwreck carrying ingots of Egyptian blue glass. Also the Amarna letters, a diplomatic archive of the House of the King's correspondence, include requests for glass. The presence of metals such as copper, lead and antimony in strong coloured, opaque glass triggers interesting questions concerning the origin of the raw materials used for glassmaking, and whether such sources are the same as the ones used in metallurgy.

The oldest copper objects containing variable levels of arsenic (As) and/or Sb (1-20\% by weight) have been found in the southern Levant and by far predate the earliest glass. The finds of the Nahal Mishmar

\footnotetext{
* Corresponding author. Department of Earth and Environmental Sciences, Katholieke Universiteit Leuven, Celestijnenlaan 200 E, 3001, Heverlee, Belgium.

E-mail addresses: Patrick.Degryse@kuleuven.be, p.a.i.h.degryse@arch.leidenuniv.nl (P. Degryse), a.shortland@cranfield.ac.uk (A.J. Shortland), Sarah.Dillis@

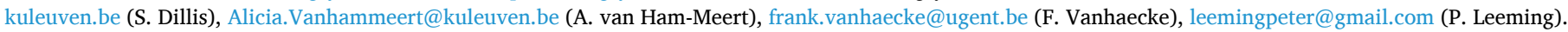


hoard are dated to 4600-3500 BCE (Shalev and Northover, 1993). Copper objects with significant $\mathrm{Sb}$ and As contents have also been identified at various sites in central Italy, dated from the early 4th millennium BCE until the Early Bronze Age. Also, Sb metal beads have been found in central Italy, where the oldest context at the site of Ponte San Pietro dates to 3635-3376 cal BC (Dolfini, 2014). In the Caucasus, copper objects containing up to $20 \%$ Sb by weight, sometimes also with As, date from possibly the end of the Early Bronze Age (late 4th millennium BCE) and definitely the Middle Bronze Age (early 2nd millennium BCE). They differ from the previously discussed Sb-rich metal objects in their minor to trace element composition. During the Late Bronze Age, from the middle of the 2nd millennium BCE onwards, the use of Sb-rich copper objects became widespread in the region, especially in the northern Koban area (Hauptmann and Gambaschidze, 2001; Meliksetian et al., 2003; Meliksetian and Pernicka, 2010; Pike, 2002). All the aforementioned Sb-rich $\mathrm{Cu}$ objects must be considered natural alloys, derived from smelting complex ores. Also metallic Sb objects have been widely reported in the southern Caucasus, the earliest finds dating to the middle of the 3rd millennium BCE, and becoming more prominent during the 2nd millennium BCE from sites in Armenia, Dagestan and Georgia (e.g. Chernykh, 1992; Meliksetian et al., 2003).

The most likely origin for the $\mathrm{Sb}$ used as an opacifier in ancient glassmaking throughout the Near East has therefore been suggested to lie in the Caucasus (Shortland, 2002b), where Sb-rich minerals were specifically mined during the Bronze Age. The earliest dated exploitation of stibnite there, the Zopkhito mine, is securely placed in the 17th century BCE (Chernykh, 1992), just before the start of widespread glass production. The area is more commonly known, however, for gold mining. Here, we use the $\mathrm{Sb}$ isotopic analysis to link the earliest glass to these $\mathrm{Sb}$ raw materials.

\section{Materials and methods}

\subsection{Geological materials}

A collection of 99 Sb-rich ores from various regions around the world, obtained mostly from mineralogical museums, allowed for the exploration of the nature of Sb-rich mineral resources, their geological formation and their mineralogical and chemical characteristics (Dillis, 2020). Such inventory not only highlights the major Sb ore minerals occurring, but also represents peculiar minerals that can host exotic chemical elements, particular for a given deposit or mining district. A subset of the ores was analysed by X-ray diffraction (XRD) and inductively coupled plasma atomic/optical emission spectroscopy (ICP-OES) for complete mineralogical and elemental characterisation, and for their $\mathrm{Sb}$ isotopic composition. A full description of the samples is given in Lobo et al. (2012, 2013; 2014), Degryse et al. (2015) and Dillis et al. (2019).

\subsection{Archaeological materials and context}

The Mestia-Racha locality in the Republic of Georgia contains a dense concentration of prehistoric sites associated with early metallurgy. Approximately 100 locations have been discovered at which $\mathrm{Cu}$, $\mathrm{Sb}$ and As ores were worked (Chernykh, 1992). Ores were extracted both from surface quarries and from underground shafts, some with sharply sloping galleries. The largest $\mathrm{Cu}$ mines in the region are Chkornali and Chvesho. There is, admittedly ambiguous, typo-chronological evidence that the exploitation of $\mathrm{Cu}$ deposits of the Upper Racha ridge began during the middle Bronze Age (Chernykh, 1992). However, more detailed investigation of the ancient mines strongly suggested that their exploitation began in the subsequent Late Bronze Age period only. There are also several major deposits of Sb which were exploited in prehistoric times. Three major Sb deposits in Gona, Zopkhito and Sagebi have been pinpointed by metallurgical research (Inanishvili et al., 2010), and those in the vicinity of the village of Gona are the closest to population centres and therefore the most accessible. During September 10-12, 2016, an expedition led by P. Leeming and the Georgian National Museum (GNM) collected Rachan material, including material from the site Chkornali 1 (N 42 49' 21.6”; E 43 32' 51.5”; 2429 m elevation). The mine was found to be flooded, but three samples were collected 5 and $15 \mathrm{~m}$ from the entrance. Other samples, obtained from museum collections, were taken close to the Zopkhito Sb deposit, which was extensively explored for Sb in the 1940s and 1950s, with samples originating from ancient sloping galleries and pit faces. The earliest of a series of radiocarbon dates on charcoal found in the Zopkhito and Sagebi mines dates the beginning of exploitation to at least the 17th century BCE (Chernykh, 1992). Traces of Sb smelting have been found near the Zopkhito ore body (Chernykh, 1992).

Fourteen $\mathrm{Sb}$ metal beads found at the site of Brili, excavated from stone grave 32 ( 11 beads) and grave 1 ( 3 beads), were also analysed. The G32 beads were part of three different necklaces. Each bead in necklaces A and B is bi-lobed. They consist of two spherical bodies that share a common flat base. Such beads are typical grave goods in the tombs of Brili, Nuli and Kvasatali (Shida Kartli) (Hauptmann and Gambaschidze, 2001). Each bead in necklace $C$ is tri-lobed, consisting of three spherical bodies. Brili is a multi-period cemetery in the region of Racha-Lechkumi, situated to the west of the area of Gona. The site was excavated in nine seasons between 1939 and 1961 under the leadership of G. Gobejishvili (1977). Even though the cemetery was not completely excavated, more than 200 graves were opened. Local communities used the cemetery intermittently as a burial ground for about 2000 years from the early second millennium BCE (Middle Bronze Age) to the 4th century CE. They are characterized by diverse belief systems and mortuary practices - earthen pit graves, stone cists, and cremation platforms (Sagona, 2017). The site has only been dated by relative chronology and burial-by-burial analysis is ongoing, with thus far limited publications (e.g. Pantskhava et al., 2001). This lack of absolute dating is in line with the Bronze Age of Western Georgia as a whole, which has acidic soils such that little survives to be dated, whereas Eastern Georgia fares better. Current ${ }^{14} \mathrm{C}$ dating programs are ongoing.

Also analysed are four beads representing five different necklaces recovered from graves in the Chalipiragorebi cemetery in Tbilisi. One sample belongs to a composite spacer-plate necklace comprising more than 80 beads, from grave 15 , from which a bead shaped like an axe was analysed. One sample is a flattened truncated bicone or lozenge bead, recovered from grave 75 . The remaining samples of necklaces were found in grave 3 . This cemetery was in use during the 16th to 13th centuries BCE. Unfortunately, outside Georgia little contextual information has been published thus far, but the necklace from grave 15 is briefly described and illustrated in Hauptmann and Gambaschidze (2001: 151, 280, no 98).

\subsection{Methods}

The Racha ores and Brili and Chalipiragorebi metal beads were analysed to determine their elemental composition by inductively coupled plasma - optical emission spectrometry (ICP-OES) and inductively coupled plasma - mass spectroscopy (ICP-MS). Sb isotope ratio measurements were accomplished using multi-collector ICP-MS. The Mesopotamian and Egyptian Late Bronze Age glass described here was previously analysed (Degryse et al., 2015).

\subsection{1. $X R D$}

Ores were crushed in an agate mortar and placed on the XRD holder using silica gel. Powders were measured using a Phillips PW1830 diffractometer with a Bragg/Brentano $\theta-2 \theta$ setup and $\mathrm{Cu} K \alpha$ radiation at $45 \mathrm{kV}$ and $30 \mathrm{~mA}$. Angles from $5^{\circ}$ to $75^{\circ} 2 \theta$ were scanned with a step size of $0.02^{\circ} 2 \theta$ and 1 s per step. ConvX software was used for file conversion, and mineral identification was achieved using DiffracPlus (EVA). 


\subsubsection{ICP-OES}

The major and minor elemental compositions of the ore collection samples were determined by ICP-OES using a Varian 720-ES instrument (simultaneous ICP-OES with axially viewed plasma). The powdered samples were digested in Teflon beakers using a mixture of $3 \mathrm{ml} 12 \mathrm{M}$ $\mathrm{HCl}$ and $1 \mathrm{ml} 14 \mathrm{M} \mathrm{HNO}_{3}$ (aqua regia). The samples were heated overnight and then evaporated at $110^{\circ} \mathrm{C}$. We then added $3 \mathrm{ml} 28.9 \mathrm{M} \mathrm{HF}$ to the residue and heated and evaporated the samples as above. Finally, we added $3 \mathrm{ml}$ of $1 \mathrm{M} \mathrm{HNO}_{3}$ to the residue and the solution was transferred into a larger tube (15-ml capacity) before diluting to $8 \mathrm{ml}$ by adding another $5 \mathrm{ml}$ of $1 \mathrm{M} \mathrm{HNO}_{3}$. Three $\mathrm{ml}$ was retained for ICP-OES analysis. The instrumental setup is described in Brems et al. (2012) and the operating conditions and parameters are summarised in the Supplemental Materials (Table S1).

Major and minor element concentrations in the Sb metal beads were determined by ICP-OES using the same Varian 720-ES instrument after aqua regia digestion identical to the one described for the ores.

\subsubsection{ICP-MS}

Trace elemental compositions of the Sb metal beads were determined with inductively coupled plasma - mass spectrometry (ICP-MS) using an Agilent7700X in the $\mathrm{He}$ mode using ${ }^{72} \mathrm{Ge}$ as internal standard, measuring sample aliquots taken from the digestion for ICP-OES analysis. Reference standard solutions NIST SRM1643f and Environment Canada TM-35 (lot 0317) were used for quality assurance.

\subsection{4. $M C-I C P-M S$}

Originally, Sb isotopic analysis involved the isolation of Sb using a combination of cation exchange chromatography with Dowex resin and anion exchange chromatography using Amberlite resin (Degryse et al., 2015; Lobo et al., 2012, 2013; 2014). This procedure is continued for materials containing low levels of $\mathrm{Sb}$ as no loss or fractionation is observed. For samples with a high Sb content, the elution profiles indicated a major loss of $\mathrm{Sb}$. Hence, a new procedure was introduced, and $\mathrm{Sb}$ solutions were loaded for isotopic measurements without prior exchange chromatography.

For new Sb isotopic analyses carried out in the context of this study, samples were weighed in Savillex beakers to which $4 \mathrm{ml}$ of aqua regia was added (see above). The mixtures were heated overnight and then evaporated at $110{ }^{\circ} \mathrm{C}$ before adding $3 \mathrm{ml} 28.9 \mathrm{M} \mathrm{HF}$, repeating the heating/evaporation step and then dissolving the residues in $10 \mathrm{ml} 3 \%$ $\mathrm{HNO}_{3}$ for the concentration check (determination of the target element concentration, thus allowing concentration-matching of samples and external standard) and isotope ratio measurement. The concentration of $\mathrm{Sb}$ was determined using a quadrupole-based PerkinElmer SCIEX Elan 5000 ICP-MS instrument. Calibration was accomplished using external calibration while an internal ruthenium $(\mathrm{Ru})$ standard was used to correct for matrix effects, signal drift and instrument instability. Sb isotope ratios were determined by MC-ICP-MS at Ghent University (Belgium), using a Neptune multi-collector ICP-MS unit (Thermo Fisher Scientific) equipped with a $100 \mu \mathrm{min}^{-1}$ micro-flow PFA-50 Teflon nebulizer and a double spray chamber, consisting of cyclonic and Scotttype sub-units for sample introduction. The instrument was run in static multi-collection mode with the ion signal intensities of ${ }^{121} \mathrm{Sb}$ and ${ }^{123} \mathrm{Sb}$ detected simultaneously by multiple Faraday cups (see Supplemental Materials, Table S2 for operating conditions). Indium (In) was used as an internal standard $\left({ }^{113} \mathrm{In}\right.$ and $\left.{ }^{115} \mathrm{In}\right)$ to correct for instrumental mass discrimination according to the revised Russell's law (Baxter et al., 2006). The latter method is more repeatable and reproducible than external sample-standard bracketing (SSB) only (Lobo et al., 2013). Sb isotope ratio results are reported in ${ }^{123} \varepsilon$ units, which express the isotopic composition of $\mathrm{Sb}$ as a relative difference or deviation with respect to an in-house standard (SPC Science), measured in a standard-sample-standard bracketing sequence containing $1000 \mathrm{ppb} \mathrm{Sb}$ and $150 \mathrm{ppb}$ In as an internal standard (Lobo et al., 2012, 2013; 2014).

\section{Results}

The average abundance of $\mathrm{Sb}$ in the Earth's crust is only $\sim 0.2 \mathrm{mg} / \mathrm{kg}$ (0.2 ppm), making the element almost as scarce as silver (Ag). Native Sb is extremely rare. A summary of the mineralogical analysis of the ores is shown in Table 1 , a summary of the geochemical analysis in Table 2. Stibnite $\left(\mathrm{Sb}_{2} \mathrm{~S}_{3}\right)$ was the ore most frequently identified, followed by tetrahedrite $\left((\mathrm{Cu}, \mathrm{Fe})_{12} \mathrm{Sb}_{4} \mathrm{~S}_{13}\right)$ and boulangerite $\left(\mathrm{Pb}_{5} \mathrm{Sb}_{4} \mathrm{~S}_{11}\right)$. Most stibnite is very pure, with minor contents of $\mathrm{As}, \mathrm{Pb}$ and/or zinc $(\mathrm{Zn})$ present in only a few cases. The tetrahedrite-tennantite mineral series is associated with high levels of $\mathrm{Cu}$, iron (Fe) and often As and $\mathrm{Zn}$, whereas boulangerite contains high amounts of $\mathrm{Pb}$. The elemental composition of the ores leads us to conclude that the use of stibnite in ancient industries would not contribute many elements to the end product other than $\mathrm{Sb}$ and S. In glassmaking, stibnite was thus the only viable mineral raw material that could be used as an opacifier while keeping strict control over the glass composition and hence its (opaque) colour. Based on their ubiquity in ore deposits, only tetrahedrite and boulangerite are likely alternative ore minerals, but these would introduce other elements in significant amounts in glass making, as would other minerals such as e.g. bindheimite $\left[\mathrm{Pb}_{2} \mathrm{Sb}_{2} \mathrm{O}_{6}(\mathrm{O}, \mathrm{OH})\right]$. The association of $\mathrm{Cu}, \mathrm{Sb}, \mathrm{As}, \mathrm{Fe}, \mathrm{Pb}$ and other elements in polymetallic minerals is the basis for the fact that $\mathrm{Sb}$-rich $\mathrm{Cu}$ objects are considered natural alloys derived from smelting complex ores.

In this study, Late Bronze Age Mesopotamian and Egyptian vessel glass and Late Bronze Age Sb metal beads from the Southern Caucasus, originating from the Brili and Chalipirogrebi cemeteries and dated between the 15th and 10th centuries BCE, are compared to stibnite ore deposits possibly exploited in the ancient world. In particular ores from different deposits in the Racha-Lechkumi region (Zopkhito, Ghebi and Chkornali) and the Sb metal beads were newly analysed (Table 3).

It has to be noted that the assumption of a one-to-one relationship between mineral raw materials and artefacts, so that the geological signature is not transformed chemically during the manufacturing process of ancient materials, is not necessarily fulfilled when considering the $\mathrm{Sb}$ isotope ratio. Isotopic fractionation has been reported for $\mathrm{Sb}$ during the investigation of hydrothermal geological systems and environmental systems such as waste combustion and metal smelting (Rouxel et al., 2003). Positive to zero $\varepsilon^{123} \mathrm{Sb}$ values for natural sources of $\mathrm{Sb}$ versus negative $\varepsilon^{123} \mathrm{Sb}$ values for anthropogenic inputs are reported (Tanimizu et al., 2011; Wen et al., 2018), based on a consistent fractionation of around $-3^{123} \varepsilon$ units in ore processing, explained by evaporation in the roasting and smelting process (Weiss et al., 2008). Fractionation experiments were set up, showing a fractionation of 3-epsilon during technological processing when the oxidation state of $\mathrm{Sb}$ changes (varying between the metallic state $\mathrm{Sb}^{0}$ and valences $\mathrm{Sb}^{3+}$ or $\mathrm{Sb}^{5+}$ ) and when loss is possible (in an open system) (Dillis et al., 2019). The Sb isotope ratio of newly produced opacified glass was shown to be effectively $\sim 3.0{ }^{123} \varepsilon$ units lower than the unprocessed ore, consistent with values known from previous studies of modern processing of $\mathrm{Sb}$ and its behaviour in the environment. The data reported here are thus graphically presented showing a 3-epsilon correction for the archaeological artefacts.

The Caucasian Sb metal beads were found to represent two

Table 1

Minerals identified by XRD.

\begin{tabular}{|c|c|c|}
\hline Mineral & $\mathrm{N}=90$ & Associated minerals \\
\hline Stibnite $\left(\mathbf{S b}_{2} \mathrm{~S}_{3}\right)$ & 64 & $\begin{array}{l}\text { stibiconite, berthierite, chalcopyrite, } \\
\text { galena, sphalerite }\end{array}$ \\
\hline Tetrahedrite $\left((\mathrm{Cu}, \mathrm{Fe})_{12} \mathrm{Sb}_{4} \mathrm{~S}_{13}\right)$ & 4 & $\begin{array}{l}\text { galena, pyrite, sphalerite, } \\
\text { chalcopyrite }\end{array}$ \\
\hline Boulangerite $\left(\mathrm{Pb}_{5} \mathrm{Sb}_{4} \mathrm{~S}_{11}\right)$ & 4 & $\begin{array}{l}\text { falkmanite, galena, zincite, } \\
\text { sphalerite }\end{array}$ \\
\hline Other Sb-rich minerals & 18 & \\
\hline
\end{tabular}


Table 2

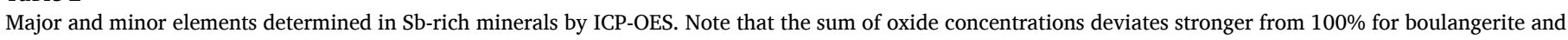

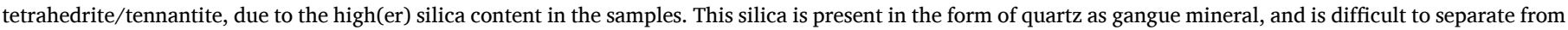
the dispersed ore mineral.

\begin{tabular}{|c|c|c|c|c|c|c|c|c|c|}
\hline \multicolumn{10}{|c|}{ Stibnite (median, $\mathrm{n}=60$ ) } \\
\hline \multicolumn{7}{|c|}{ Major to minor } & \multicolumn{3}{|c|}{ Gangue material (excl. silica) } \\
\hline $\mathrm{Sb}$ & $\mathrm{S}$ & $\mathrm{Pb}$ & As & $\mathrm{Fe}$ & $\mathrm{Zn}$ & & $\mathrm{Ca}$ & $\mathrm{Al}$ & $\mathrm{K}$ \\
\hline $74.6 \%$ & $27.1 \%$ & $0.5 \%$ & $0.3 \%$ & $0.3 \%$ & $0.1 \%$ & & $0.3 \%$ & 0.3 & $0.1 \%$ \\
\hline \multicolumn{10}{|c|}{ Tetrahedrite/tennantite (mean, $n=4$ ) } \\
\hline \multicolumn{7}{|c|}{ Major to minor } & \multicolumn{3}{|c|}{ Gangue material (excl. silica) } \\
\hline $\mathrm{Cu}$ & $\mathrm{S}$ & $\mathrm{Sb}$ & As & $\mathrm{Zn}$ & $\mathrm{Fe}$ & $\mathrm{Bi}$ & $\mathrm{Ca}$ & $\mathrm{Mg}$ & \\
\hline $39.1 \%$ & $24.9 \%$ & $14.5 \%$ & $8.7 \%$ & $4.0 \%$ & $2.3 \%$ & $0.1 \%$ & $0.5 \%$ & $0.3 \%$ & \\
\hline \multicolumn{10}{|c|}{ Boulangerite (mean, $n=4$ ) } \\
\hline \multicolumn{7}{|c|}{ Major to minor } & \multicolumn{3}{|c|}{ Gangue material (excl. silica) } \\
\hline $\mathrm{Sb}$ & $\mathrm{Pb}$ & $\mathrm{S}$ & As & $\mathrm{Fe}$ & Mn & & $\mathrm{Ca}$ & $\mathrm{Mg}$ & \\
\hline $25.4 \%$ & $6.5 \%$ & $5.6 \%$ & $1.0 \%$ & $0.7 \%$ & $0.1 \%$ & & $0.5 \%$ & $0.3 \%$ & \\
\hline
\end{tabular}

compositional groups in terms of $\mathrm{Sb}$ isotopic composition and minor to trace element contents (Table 3, Fig. 1). Half of the beads were nearly pure $\mathrm{Sb}$, with variable levels of $\mathrm{Cu}$ (up to $1.5 \mathrm{wt} \%$ ) and As (up to 3500 $\mu \mathrm{g} / \mathrm{g})$, a low silver content $(<20 \mu \mathrm{g} / \mathrm{g})$ and occasional elevated trace contents of Bi and Ni. They matched well with the Sb isotopic composition of the Racha-Lechkumi stibnite ores when corrected for a 3epsilon fractionation. Interestingly, direct comparison of the $\mathrm{Sb}$ isotope ratios in the Brili and Chalipiragorebi metal beads and the local stibnite ores of the Racha-Lechkumi district revealed no correspondence, as if the metallic Sb beads were made from raw materials imported from another region. Nevertheless, in view of the uniqueness of the Caucasian deposits, the strong archaeological tie between these ores and the very existence of Sb metal artefacts, the occurrence of consistent fractionation of $\mathrm{Sb}$ isotopes during processing effectively stands as more likely. A second compositional group of $\mathrm{Sb}$ metal beads also shows variable levels of $\mathrm{Cu}$ (up to $5 \mathrm{wt} \%$ ) and As (up to $6000 \mu \mathrm{g} / \mathrm{g}$ ), but are associated with an elevated content in $\mathrm{Ag}$ (between 29 and $189 \mu \mathrm{g} / \mathrm{g}$ ) and have occasional elevated trace contents in $\mathrm{Au}, \mathrm{Mo}, \mathrm{Pb}, \mathrm{Zn}$ and $\mathrm{Sn}$. . The second compositional group of $\mathrm{Sb}$ beads does not match the (corrected) $\mathrm{Sb}$ isotopic composition of the Racha-Lechkumi stibnite ores. Admittedly, no further Sb ores from Georgia or Armenia (including tetrahedrite-tennantite, boulangerite or native antimony) were available for analysis, but the different $\mathrm{Sb}$ isotopic and minor/trace element associations do suggest the use of a different ore for this second compositional group of Sb metal beads. The production of antimony metal objects in more than one location in the Caucasian Bronze Age, using different ores, has been suggested before by Meliksetian et al. (2003) on the basis of $\mathrm{Pb}$ isotopic analysis. Note the high lime contents in all beads, likely related to the presence of (secondary) calcite or gypsum in the beads, though this could not be confirmed by mineralogical analysis due to the small sample size.

When we considered the corrected $\mathrm{Sb}$ isotopic composition of Egyptian and Mesopotamian Late Bronze Age glass (Degryse et al., 2015), we found that the Sb isotopic composition of these materials closely matched the Racha-Lechkumi stibnite, and we observed no systematic differences between the Mesopotamian and Egyptian artefacts (all blue opaque glass). However, the glass did not match the corrected signature, and hence the ore source, of the Cu-rich Sb beads. Two other previously analysed materials (Degryse et al., 2015) show a very similar $\mathrm{Sb}$ isotopic composition to Late Bronze Age glass and correspond to the Racha-Lechkumi stibnite ores: a metallic Sb bead, found at Jerablus Tahtani (Syria) and dated to 2300-2500 BCE (Shortland, 2002b), and a white opaque material (Gambaschidze and Hauptmann, 2013), dated to 2000 BCE and found in Sagebis Dsiri in the Racha district. The white opaque material may correspond to the first known remains of the processing of Sb resources from the area (Degryse et al., 2015). Moreover, the glass and beads show no other matches with known stibnite, apart from single ore samples from Austria and Romania (Lobo et al., 2012), locations from which no Sb processing is known.

\section{Discussion}

Stibnite is the only mineral that can provide sufficiently pure Sb raw material to opacify glass. The Racha-Lechkumi stibnites are the only known source that match the composition of Late Bronze Age glass. Remarkably, the Sb deposits in the Sagebi, Kairobi, Sanartskhia, Kvardzakheti and Zopkhito mines are all associated with Au mineralization (Mindat, https://www.mindat.org/min-3782.html, last visited on 27/04/2020). Moreover, gold extraction in the region, from Sakdrisi, is known from the first half of the 4th millennium BCE onwards (Stoellner and Gambashidze, 2011). The region is geologically a narrow Jurassic slate belt that follows the Greater Caucasus, and is characterized by anomalously high concentrations of $\mathrm{Sb}, \mathrm{Cu}, \mathrm{Zn}$ and $\mathrm{Au}$ due to hydrothermal alteration. In addition, narrow horizons of diagenetic pyrite are found, enriched in As, Au and Sb, and provide a likely source for younger epigenetic metal enrichments (Kekelia et al., 2008).

The geology of the Caucasian antimony deposits is not the only connection between the earliest glass and gold. The first white and yellow glass, made with antimonate opacifiers, was applied to the edges of the lids and feet of glass vessels, in the same manner as Au leaf (Lilyquist and Brill, 1993). While the Sb in Egyptian yellow glasses appears to come from the Caucasus, most of the $\mathrm{Pb}$ for the yellow antimonate colorant appears to originate from galena deposits extracted from the mines of Gebel Zeit in the Eastern Desert of Egypt (Shortland, 2012). Conversely, the few and earliest yellow glasses dated to the reigns of Tuthmosis III and Amenhotep II have significantly different $\mathrm{Pb}$ isotope ratios, close to the small number of compositions available for yellow glass from the Near East, suggested to be a "Mesopotamian field" (Lilyquist and Brill, 1993), in the meantime confirmed through the analysis of Kassite and Nuzi glass, although their ore source remains unknown. The earliest technology for yellow glass thus appears to have travelled through Mesopotamia to Egypt, where it was adapted using local $\mathrm{Pb}$ ores.

\section{Conclusion}

Despite the ubiquitous use of $\mathrm{Sb}$ as a raw material in ancient glassmaking, its procurement has only rarely been studied in detail. Connections between Egypt and Mesopotamia on the one hand, and the Caucasus on the other, have been shown in the likely origin of stibnite as a mineral raw material for glass opacifying, originating in the RachaLechkumi district. The earliest technology for yellow glass, made with $\mathrm{Pb}$ antimonate, thus travelled through Mesopotamia to Egypt, where it was adapted using local $\mathrm{Pb}$ ores. We propose that stibnite extraction was driven by the demand for glass, independent of Cu metallurgy. However, early glassmaking may be linked to Au metallurgy, as yellow glass may have been a replacement for this precious metal, and stibnite and gold extraction at least geologically co-occurred. 


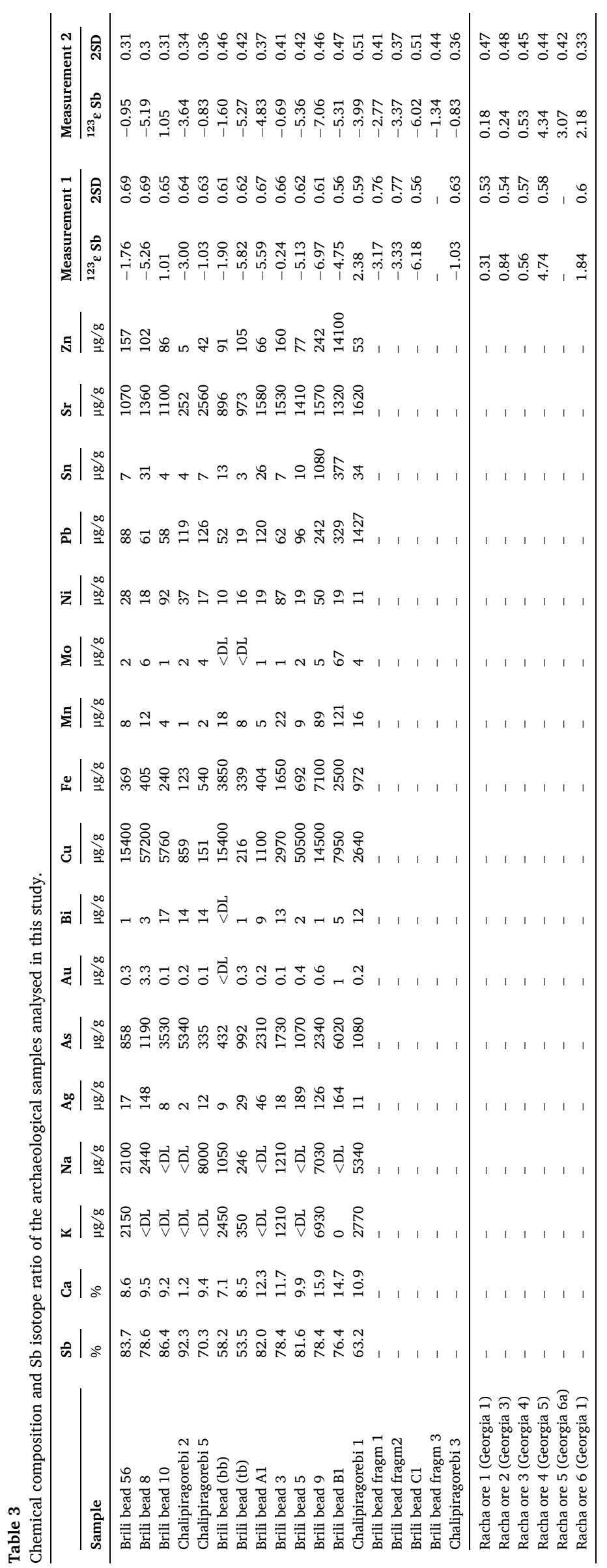

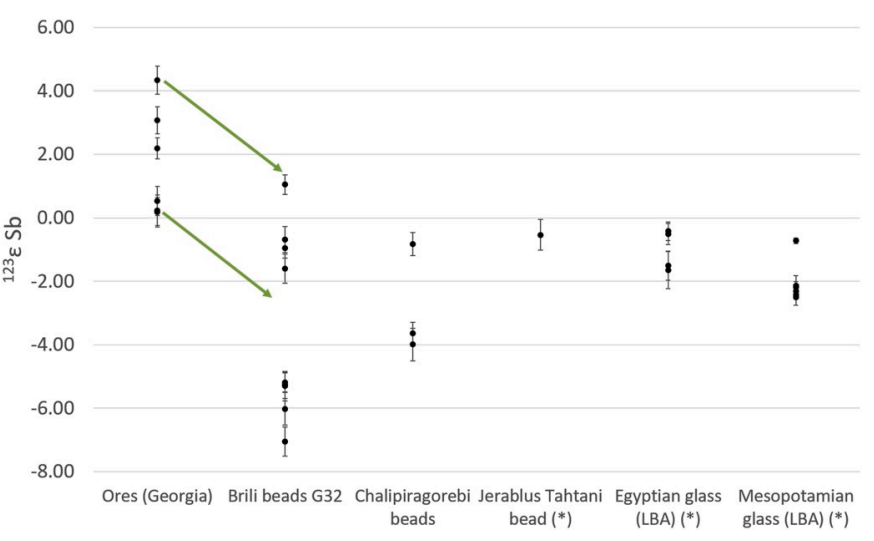

Fig. 1. Sb isotopic composition of Caucasian stibnite from the Racha-Lechkumi region and $\mathrm{Sb}$ metal beads from Brili and Chalipiragorebi, compared to previously analysed Egyptian and Mesopotamian Late Bronze Age glasses (Degryse et al., 2015). The arrows show the 3-epsilon correction for fractionation between the unprocessed ores and the archaeological artefacts.

\section{Declaration of competing interest}

The authors declare that they have no known competing financial interests or personal relationships that could have appeared to influence the work reported in this paper.

\section{Acknowledgments}

We are grateful to Elvira Vassilieva for help with sample preparation and ICP-OES/MS analysis, and Kris Latruwe (Ghent University) for running the Neptune measurements. This paper benefited greatly from a Visiting Fellowship by PDG at All Souls College, Oxford. We acknowledge the Georgian National Museum and Royal Belgian Institute of Natural Sciences (KBIN) for permission to sample the metallic beads and stibnite ores, respectively. Funding: The research was financially supported by the Flemish Research Foundation (FWO Vlaanderen) [grant no. G0C4315N] and the KU Leuven Special Research Fund [grant no. C14/19/060]. Author contributions: PDG and AJS wrote the paper, designed the methodology and conceptualized the research, SD AVHM, and FV performed the investigation and analytical work, PL performed sampling in the field.

\section{Appendix A. Supplementary data}

Supplementary data to this article can be found online at https://doi. org/10.1016/j.jas.2020.105195.

\section{References}

Baxter, D.C., Rodushkin, I., Engström, E., Malinovsky, D., 2006. Revised exponential model for mass bias correction using an internal standard for isotope abundance ratio measurements by multi-collector inductively coupled plasma mass spectrometry. J. Anal. Atomic Spectrom. 21, 427-430.

Brems, D., Degryse, P., Hasendoncks, F., Gimeno, D., Silvestri, A., Vassilieva, E., Luypaers, S., Honings, J., 2012. Western mediterranean sand deposits as a raw material for roman glass production. J. Archaeol. Sci. 39, 2897-2907.

Chernykh, E.N., 1992. Ancient Metallurgy in the USSR: the Early Metal Age. Cambridge University Press, Cambridge, MA.

Degryse, P., Boyce, A., Erb-Satullo, N., Eremin, K., Kirk, S., Scott, R.B., Shortland, A.J., Schneider, J., Walton, M., 2010. Isotopic discriminants between late Bronze Age glasses from Egypt and the Near East. Archaeometry 52 (3), 380-388.

Degryse, P., Lobo, L., Shortland, A.J., Vanhaecke, F., Blomme, A., Painter, J., Gimeno, D., Eremin, K., Greene, J., Kirk, S., Walton, M., 2015. Isotopic investigation into the raw materials of late Bronze Age glass making. J. Archaeol. Sci. 62, 153-160.

Dillis, S., 2020. Antimony as a Raw Material for Making Metal and Vitreous Materials from the Bronze Age to the Roman Period. KU Leuven. Unpublished PhD thesis.

Dillis, S., Van Ham-Meert, A., Leeming, P., Shortland, A.J., Gobejishvili, G., Abramishvili, M., Degryse, P., 2019. Antimony as A raw material in ancient metal and glass making: provenancing Georgian LBA metallic Sb by isotope analysis. STAR Sci. Technol. Archaeol. Res. J. https://doi.org/10.1080/20548923.2019.1681138. 
Dolfini, A., 2014. Early metallurgy in the central mediterranean. In: Roberts, B.W., Thornton, C.P. (Eds.), Archaeometallurgy in Global Perspective: Methods and Syntheses, pp. 559-578. Heidelberg.

Gambaschidze, I., Hauptmann, A., 2013. The Bronze Age metallurgy in Southern Georgia: the origin of gold and base metal artefacts. In: Paper Presented at the Northern Frontier of Near Eastern Archaeology: Recent Research on Caucasia and Anatolia in the Bronze Age, Humboldt Kolleg International Conference, Venice, Italy, 9-11 January 2013. http://venus. unive.it/erovaweb/convegno/abstracts.pdf.

Gobejishvili, G., 1977. Brili. Georgian SSR encyclopedia 2, p. 522 [in Georgian and

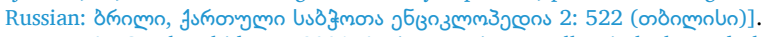

Hauptmann, A., Gambaschidze, I., 2001. Antimon - eine metallurgische besonderheit aus Dem Kaukasus. In: Georgien - Schätze Aus Dem Land Des Goldenen Vlies, Bochum, pp. 150-155.

Inanishvili, G., Maisuradze, B., Gobejishvili, G., 2010. Mining and Metallurgical Activity in Ancient Georgia (3rd-1st Millennium B.C.). Artlines, Tbilisi.

Kekelia, S.A., Kekelia, M.A., Kuloshvili, S.I., Sadradze, N.G., Gagnidze, N.E., Yaroshevich, V.Z., Asatiani, G.G., Doebrich, J.L., Goldfarb, R.J., Marsh, E.E., 2008. Gold deposits and occurrences of the greater Caucasus, Georgia republic: their genesis and prospecting criteria. Ore Geol. Rev. 34, 369-386.

Kemp, V., McDonald, A., Brock, F., Shortland, A.J., 2020. LA-ICP-MS analysis of Late Bronze Age blue glass beads from Gorub, Egypt. Archaeometry 62 (1), 42-53.

Lilyquist, C., Brill, R.H., 1993. Studies in Ancient Egyptian Glass. Metropolitan Museum of Art, New York.

Lobo, L., Devulder, V., Degryse, P., Vanhaecke, F., 2012. Investigation of natural isotopic variation of $\mathrm{Sb}$ in stibnite ores via multi-collector ICP-mass spectrometry perspectives for Sb isotopic analysis of roman glass. J. Anal. Atomic Spectrom. 27, 1304-1310.

Lobo, L., Degryse, P., Shortland, A.J., Vanhaecke, F., 2013. Isotopic analysis of antimony using multi-collector ICP-mass spectrometry for provenance determination of roman glass. J. Anal. Atomic Spectrom. 28, 1213-1219.

Lobo, L., Degryse, P., Shortland, A.J., Eremin, K., Vanhaecke, F., 2014. Copper and antimony isotopic analysis via multi-collector ICP-mass spectrometry for provenancing ancient glass. J. Anal. Atomic Spectrom. 29, 58-64.

Meliksetian, K., Pernicka, E., 2010. Geochemical characterisation of Armenian Early Bronze Age metal artefacts and their relation to copper ores. In: Von Maikop bis Trialeti. Gewinnung und Verbreitung von Metallen und Obsidian in Kaukasien im 4.2. Jt. v. Chr., Beiträge des Internationalen Symposiums in Berlin vom 1.-3. Juni 2006. Kolloquien zur Vor- und Frühgeschichte, Band 13, Bonn, pp. 41-58.

Meliksetian, K., Pernicka, E., Avetissyan, P., Simonyan, H., 2003. Chemical and lead isotope characterisation of Middle Bronze Age bronzes and some Iron Age antimony objects (Armenia). In: Proc. Of the Intern. Conf. Archaeometallurgy in Europe, Milan, pp. 311-318.

Pantskhava, L., Maisuradze, B., Gobejishvili, G., 2001. Toward dating burial No.12

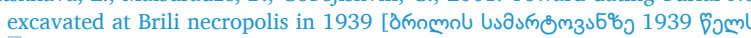

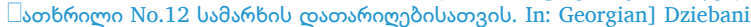
[dojßs6o], vol. 8, pp. 39-45.

Pike, A., 2002. Analysis of caucasian metalwork - the use of antimonal, arsenical and tin Bronze in the late Bronze Age. In: Ancient Caucasian and Related Materials in the British Museum, vol. 121. British Museum Occasional Paper, London, pp. 89-92.

Rouxel, O., Ludden, J., Fouquet, Y., 2003. Antimony isotope variations in natural systems and implications for their use as geochemical tracers. Chem. Geol. 200, 25-40.

Sagona, A., 2017. The Archaeology of the Caucausus. From Earliest Settlements to the Iron Age. Cambridge World Archaeology, New York.

Shalev, S., Northover, J.P., 1993. Metallurgy of the Nahal mishmar hoard reconsidered. Archaeometry 35, 35-47.

Shortland, A.J., 2002a. The use and origin of antimonate colorants in early Egyptian glass. Archaeometry 44, 517-530.

Shortland, A.J., 2002b. An antimony bead from Jerablus Tahtani. Hist. Metall. 36, 1-5.

Shortland, A.J., 2012. Lapis Lazuli from the Kiln: Glass and Glassmaking in the Late Bronze Age. Leuven University Press, Leuven.

Shortland, A.J., Rogers, N., Eremin, K., 2007. Trace element discriminants between Egyptian and mesopotamian late Bronze Age glasses. J. Archaeol. Sci. 34, 781-789.

Shortland, A.J., Kirk, S., Eremin, K., Degryse, P., Walton, M., 2018. The analysis of late Bronze Age glass from Nuzi and the question of the origin of glassmaking. Archaeometry 60, 764-783.

Stoellner, T., Gambashidze, I., 2011. Gold in Georgia II: the oldest gold mine in the world. In: Yalçın, Ü. (Ed.), Anatolian Metal V, vol. 24. Der Anschnitt, Bochum, pp. 187-199. Beiheft.

Tanimizu, M., Araki, Y., Asaoka, S., Takahashi, Y., 2011. Determination of natural isotopic variation in antimony using inductively coupled plasma mass spectrometry for an uncertainty estimation of the standard atomic weight of antimony. Geochem. J. 45, 27-32.

Weiss, D.J., Rehkämper, M., Schoenberg, R., McLaughlin, M., Kirby, J., Campbell, P.G., Arnold, T., Chapman, J., Peel, K., Gioia, S., 2008. Application of non-traditional stable-isotope systems to the study of sources and fate of metals in the environment. Environ. Sci. Technol. 42, 655-664.

Wen, B., Zhou, J., Zhou, A., Liu, C., Li, L., 2018. A review of antimony (Sb) isotopes analytical methods and application in environmental systems. Int. Biodeterior. Biodegrad. 128, 109-116. 